\title{
Cheese Yield and Texture Acceptance of Probiotic Feta Reduced Fat Cheese (using Lactobacillus acidophilus, Bifidobacterium longum, and Lactobacillus casei)
}

\author{
Tridjoko Wisnu Murti ${ }^{1, *}$, B. J. Puspitasari ${ }^{1}$, N. D. Pratiwi ${ }^{1}$, Y. Aranda ${ }^{1}$ and M. E. W. \\ Pradana $^{2}$ \\ ${ }^{1}$ Faculty of Animal Science, Universitas Gadjah Mada, Bulaksumur-Yogyakarta Indonesia
${ }^{2}$ The Assessment Institute for Food, Drugs and Cosmetics of Indonesian Council of Ulama, Special Region of
Yogyakarta
${ }^{*}$ Corresponding author. Email: tridjokomurti@mail.ugm.ac.id
}

ABSTRACT

The study was conducted to measure cheese harvest and texture acceptance of Probiotic feta reduced-fat Feta cheese. Reduced-fat milk (50\% Fat) from Peranakan Ettawa (PE) goat in Special Region of Yogyakarta. They have added Lactobacillus acidophilus (T1), Bifidobacterium longum (T2), Lactobacillus casei (T3) as compared to non-probiotic reduced_fat feta cheese (T0). They have been detected of its value on: yield, $\mathrm{pH}$, acidity, as well as texture acceptance. The yield have calculated by measuring the weight of product, the $\mathrm{pH}$ has detected using $\mathrm{pH}$ meter, the acidity has detected by titration and the texture acceptance mouth tested by entrained panellists. The raw material were complied on standard requirement. The percentage of cheese yields for T1, T2, T3 and T0 $(16.94 \pm 0.66 ; 16.63 \pm 0.85 ; 16.76 \pm$ $0.67 ; 14,46 \pm 1,41 \%$ respectively) $(\mathrm{P}>0.05)$. While the acidity of products at 0 day were significantly different $(\mathrm{P}<0.05)$

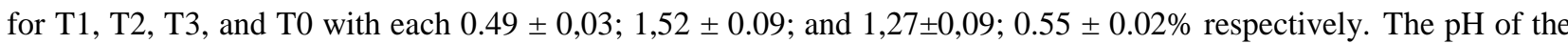
cheese have risen during 60 days of storage, and the $\mathrm{pH}$ value of $1 \mathrm{~cm}$ depth were higher than those of $4 \mathrm{~cm}$ depth $(\mathrm{P}<0.05)$. The acceptability of consumers have indicates that $\mathrm{T} 1, \mathrm{~T} 2, \mathrm{~T} 3$, and $\mathrm{T} 0$ have scored $1.83 ; 1.29 ; 1.08$, and 1.43 from maximum score 4 , respectively and were considered as dissatisfied. It has concluded that probiotic bacteria can be supplemented as a single probiotic in the production of goat reduced fat feta cheeses.

Keywords: Feta Cheese, Goat Milk, Probiotic, Cheese Yield, Texture Acceptance

\section{INTRODUCTION}

The world population of animal is going to grow and goat, either dairy or meat animals is now more than one billion. The growth of dairy goats, were influenced by goat milk demands (Miller and Lu, 2019. The number of dairy goat was estimated around 218 million heads (2017), which Asia accommodate the majority of them $(52 \%)$, then by Africa (39\%), Europe (5\%), Americas $(4 \%)$, and as well as Oceania (1\%) in regarding the statistics between the years of (2007-2017) and giving milk production around 18.7 million ton. Asia has been known as the goat continents in which $60 \%$ of the 1 billion of the Global goat population presences. Dairy goats in Indonesia are still used only as show animals, which the price of animals depends on their status as champion or not, and are still neglected for milk production, despite small quantity of milk from Yogyakarta region is collected and sell as frying milk powder. The population of over all type of Indonesia's goats has increased 3 million heads during 4 years (20072011, from 14.5 million to 17.5 million. The goats are distributed throughout the archipelago, in which Central Java province was dominated the population (21\%), then by East Java (16\%), as well as West Jaya (11\%). Thirty two percent of population (32\%) are kept for producing milk, which sell only as liquid and powder milk. Despite heavy smell of goat milk and milk products, goat milk products are therefore have important role for supply consumers in low to medium income countries in Asia by their excellent food nutrition, food security as well as provide well-being status to their owners.

The world dairy goat milk industry is little by little expanding. Despite provide food nutrition and food 
security, dairy goat can be managed easily by woman, children as well as old people, to gain livelihoods, especially in limited resource areas, mountain regions and landless or enable smallholders to accumulate assets lead to improve their well-being. In Europe, Dairy goat industry is well set and almost all of goat milk production are processed into many types of milk products. The cheese is well known as the most milk products especially presence in south Europe as Spain, France, Italy, Ex-Yougoslavia as well as Greece. The queen of cheese products in Mediterranean areas is Feta Cheese. It is made from small ruminants milk, especially sheep's milk or a mixture with goat's milk (by regulation goats milk presence not exceed 30\%) (Tasteatlas, 2021). Sometime Feta is made from Great ruminant as cow's milk or buffalo's milk or mix of them. In Greece, Feta is made in the region of Macedonia, Thessaly, Thrace, Epirus, the Peloponnese, and Central Greece. Feta with the mild rancid and slightly salty and acid flavour is typically considered as a semi-soft white brined cheese and consume freshly. Despite it, it is easy to be cut (Kandarakis et al., 2001). In the long time, Feta cheese was produced without the role of lactic acid bacteria. Recently, yogurt or starters of lactic acid bacteria have been introduced. Cheese has been reported can be hosted by lactic acid bacteria that considered as probiotic bacteria (Murti, et al., 2021). This study was to develop feta cheese using $100 \%$ of reduced fat milk from Peranakan Etawa goat, supplemented by probiotic bacteria, as Lactobacillus acidophilus, Bifidobacterium longum, and Lactobacillus casei, and stored at refrigeration during 60 days.

\section{MATERIALS AND METHODS}

\subsection{Materials}

The cheeses were developed using reduced_fat goat milk of breed PE (Ettawa offspring). Single probiotic of each culture from Universitas Gadjah Mada culture connection, using Lactobacillus acidophilus FNCC 005La, Bifidobacterium longum FNCC 0210-B1, or Lactobacillus casei FNCC 0090-Lc. They were incubated at $39^{\circ} \mathrm{C}$, unless for Lactobacillus casei at $30^{\circ} \mathrm{C}$ for 2 hours reaching the $\mathrm{pH} 6.2$ and added rennet (Chymax) $0.8 \mathrm{~g}$.

\subsection{Methods}

Raw goat milk, detected its sanitation_quality by alcohol gun test using 55 - 65\% alcohol, and lactodensitometer for its density (proxymates analysis, SNI, 1998 as in Murti, 2016). It was then reduced its fat content using cream separator until $50 \% \quad(\mathrm{v} / \mathrm{v})$, pasteurized at 80 0C during 10 minutes. Stocks for developing mother cultures were propagated at MRS media supplemented by L-Cysteine $\mathrm{HCl}$, galactosamine, and glucose with each $0.1 \%(\mathrm{v} / \mathrm{v})$ of the media, which then filtered at $0,22 \mu \mathrm{m}$ before usage.

Reduced fat feta cheese has been developed by introducing probiotic bacteria (La, Bl, or Lc) $10 \%$ (v/v), incubated at $39^{\circ} \mathrm{C}$ (unless for L.casei containing cheese at $30^{\circ} \mathrm{C}$ ) untill the $\mathrm{pH}$ reached 6.2-6.3, then added $0.002 \%$ of rennet (chymax_Chr Hansen) and $\mathrm{CaCl}_{2} 0.1 \%$. After $\mathrm{pH}$ reached 5.8, or clean break curd, it was cut by sterilesharp knife, to separate the whey. Curd was then placed at wood prints, with the diameter of $10 \mathrm{~cm}$, and press loaded by $0.6 \mathrm{~kg}$ during $24 \mathrm{hrs}$ for continuous whey syneres. It was then salted using $\mathrm{NaCl} 3 \%$, calculated its cheese yield before wraps packed, and stored at refrigeration during 60 days, as mentioned by (Ong, 2007). It was then take a sample for measuring $\mathrm{pH}$ at 1 and $4 \mathrm{~cm}$ of deep-hole and acidity as well as flavour note and scores.

The cheese yield have calculated by measuring the weight of product using digital scale. The $\mathrm{pH}$ level was measured by using a digital $\mathrm{pH}$ meter (PN 9410) on 2 different depth, $1 \mathrm{~cm}$, and $4 \mathrm{~cm}$ depth on days 0 and 60 according to (Murti et al., 2016). While for titratable acidity has been conducted by titration using $\mathrm{NaOH}$ (Murti et al., 2016). The texture acceptance mouth tested by 12 entrained panellists scoring from 0 to 4 classified as dislike, dissatisfied, like moderately, like very much, and like extremely. The study utilized One Way ANOVA to analyse cheese yield. The $\mathrm{pH}$ value was analysed using factorial design $(4 \times 4)$ and acidity was analysed using factorial design $(2 \times 4)$. While organoleptic were evaluated descriptively.

\section{RESULTS AND DISCUSSIONS}

\section{1. Raw Materials}

The results of raw milk used has indicated that PE goat milk has met the standard for making feta cheese. Its value on alcohol test, $\mathrm{pH}$ and titration presented the

Table 1. Raw Milk compositions

\begin{tabular}{|l|l|l|}
\hline Parameter & Fullcream & $\begin{array}{l}\text { Reduced fat } \\
\text { milk }\end{array}$ \\
\hline Alcohol test (55\%) & Negatif & Negatif \\
\hline $\begin{array}{l}\text { Specific density } \\
\text { (Kg/Liter) }\end{array}$ & 1.027 & 1.03 \\
\hline pH & 6.46 & 6.55 \\
\hline Titration (\%) & $0.24 \pm 0.01$ & $0.23 \pm 0.01$ \\
\hline Humidity (\%) & $83.02 \pm 0.40$ & $85.34 \pm 0.06$ \\
\hline Protein (\%) & $4.32 \pm 0.10$ & $4.93 \pm 0.03$ \\
\hline Fat (\%) & $7.65 \pm 0.07$ & $3.85 \pm 0.07$ \\
\hline Ash (\%) & $0.77 \pm 0.01$ & $0.47 \pm 0.65$ \\
\hline
\end{tabular}


normal good quality of goat milk. High percentage of milk fat and milk protein presented that, the animal managerially kept in good animal handling, especially its feeds. Total milk solid of this goat breed was high. Treatment to reduced milk fat have influenced significantly different between full cream milk and reduced fat milk (table 1). Overall, the quality of raw goat milk material, were compliance with standard of normal goat milk.

\subsection{Probiotic Feta Cheeses}

The $\mathrm{pH}$ of probiotic cheeses at the deep-hole 1 $\mathrm{cm}$ were generally higher than in $4 \mathrm{~cm}$ deep-hole, indicated that as probiotic cultures, they live better in deeper location or centre of the cheeses, performing better biochemical reaction, lead to $\mathrm{pH}$ value lower than in $1 \mathrm{~cm}$ deep-hole (Table 3.) as Murti et al., (2017; 2021). The acidity of probiotic cheeses have risen during 60 days of storage, indicated the probiotics bacteria still lives in cold storage, despite its low growth (Table. 2,3).

Development probiotic reduced-fat feta cheese have made significantly different as compared to those of control in total yields $(\mathrm{P}<0.05)$, despite among them, there were not significantly different. It seemed that developed matrix of cheese in presence of bacteria, due to higher acidity which have influenced coagulation of protein, were more compact and entrapped water (Murti, 2021).

\subsection{Organoleptic Performance}

Regarding the result of Kruskall Wallis test for nonparametric data of cheese sensory, It seemed that, consumers note on Feta Texture, has significantly independent and differences among the cheeses $(\mathrm{P}<0.05)$, and La-Supplemented feta has had the most hard after 60 days of storage followed by Lc-Supplemented Feta cheese, and Bl-Supplemented Feta Cheese. It was the same phenomenon, in which La-Supplemented Feta cheese was the most accepted by entrained panellists, followed by Lc-Supplemented Feta Cheese and BlSupplemented Feta Cheese.

\section{CONCLUSION}

It could be concluded, that probiotic bacteria can live in the matrix of Feta Cheese, despite low growth rate during storage 60 days in refrigeration temperatures and Bifidobacterium longum FNCC 0210-B1 has the highest acidity performances, lead to unacceptable note and score by panellists as compared to those supplemented by L.acidophilus or L casei.

Table 2. $\mathrm{pH}$ value of probiotic reduced_fat Feta Cheese

\begin{tabular}{|l|l|l|l|l|l|}
\hline \multirow{2}{*}{ Products } & \multicolumn{2}{l|}{ Storage time $0(\mathrm{~d})$} & \multicolumn{2}{l|}{ Storage time $60(\mathrm{~d})$} & \multirow{2}{*}{ Average } \\
\cline { 2 - 6 } & Depth : $1 \mathrm{~cm}$ & Depth: $4 \mathrm{~cm}$ & Depth: $1 \mathrm{~cm}$ & \multicolumn{2}{l|}{ Depth: $4 \mathrm{~cm}$} \\
\hline Control & $5.30 \pm 0.04$ & $5.26 \pm 0.01$ & $5.60 \pm 0.52$ & $5.21 \pm 0.19$ & $5.28 \pm 0.05^{\mathrm{c}}$ \\
\hline LA & $5.36 \pm 0.08$ & $5.32 \pm 0.08$ & $5.76 \pm 0.20$ & $5.57 \pm 0.27$ & $5.50 \pm 0.24^{\mathrm{d}}$ \\
\hline BL & $4.89 \pm 0.30$ & $4.59 \pm 0.04$ & $5.15 \pm 0.18$ & $4.96 \pm 0.10$ & $4.89 \pm 0.30^{\mathrm{a}}$ \\
\hline LC & $5.16 \pm 0.04$ & $5.20 \pm 0.03$ & $5.21 \pm 0.02$ & $5.18 \pm 0.02$ & $5.11 \pm 0.08^{\mathrm{b}}$ \\
\hline Average & $5.18 \pm 0.25$ & $5.09 \pm 0.33$ & $5.32 \pm 0.30$ & $5.20 \pm 0.28$ & \\
\hline
\end{tabular}

a,b,c,d Different letter at the same column explain significantly different $(\mathrm{P}<0,05)$

Table 3. Acidity of probiotic reduced_fat Feta cheeses (\%)

\begin{tabular}{|c|c|c|c|}
\hline \multirow{2}{*}{ Products } & \multicolumn{2}{|c|}{ Storage time $(d)$} & \multirow[t]{2}{*}{ Average } \\
\hline & 0 & 60 & \\
\hline Control & $0.55 \pm 0.02$ & $1.52 \pm 0.08$ & $1.04 \pm 0.54^{b}$ \\
\hline LA & $0.49 \pm 0.00$ & $0.52 \pm 0.01$ & $0.51 \pm 0.02^{a}$ \\
\hline $\mathrm{BL}$ & $1.52 \pm 0.09$ & $1.62 \pm 0.33$ & $1.57 \pm 0.27^{c}$ \\
\hline LC & $1.27 \pm 0.09$ & $1.59 \pm 0.04$ & $1.43 \pm 0.21^{c}$ \\
\hline Average & $0.96 \pm 0.47$ & $1.31 \pm 0.53$ & \\
\hline
\end{tabular}

${ }_{\mathrm{a}, \mathrm{b}, \mathrm{c}, \mathrm{d}}$ Different letter at the same column explain significantly different $(\mathrm{P}<0,05)$ 
Table 4. Yield of probiotic reduced_fat Feta Cheese (\%)

\begin{tabular}{|l|l|l|l|l|}
\hline & Control & LA & BL & LC \\
\hline Yields & $14.46 \pm 1.41^{\mathrm{a}}$ & $16.94 \pm 0.67^{\mathrm{b}}$ & $16.63 \pm 0.85^{\mathrm{b}}$ & $16.76 \pm 0.67^{\mathrm{b}}$ \\
\hline
\end{tabular}

${ }^{a, b}$ Different letter at the same row explain significantly different $(\mathrm{P}<0,05)$

Table 5. Organoleptic Performance

\begin{tabular}{|c|c|c|c|c|c|}
\hline \multicolumn{6}{|l|}{ Control } \\
\hline Sourness & Saltiness ${ }^{\text {ns }}$ & Bitterness & Taste preference & Softness & Texture acceptance \\
\hline 1.43 & 1.38 & 1.33 & 1.33 & 1.24 & 1.43 \\
\hline 1.95 & 1.38 & 3 & 0.57 & 2.33 & 1.95 \\
\hline \multicolumn{6}{|l|}{ LA } \\
\hline Sourness & Saltiness $^{\text {ns }}$ & Bitterness & Taste preference & Softness & Texture acceptance \\
\hline 0.53 & 0.92 & 0.31 & 2.14 & 1.34 & 1.83 \\
\hline 0.5 & 0.92 & 1.03 & 0.75 & 2.64 & 2.58 \\
\hline \multicolumn{6}{|l|}{$\mathrm{BL}$} \\
\hline Sourness & Saltiness ${ }^{\text {ns }}$ & Bitterness & Taste preference & Softness & Texture acceptance \\
\hline 2.04 & 1.25 & 1.38 & 1.08 & 1.42 & 1.29 \\
\hline 1.75 & 1.33 & 2.58 & 0.83 & 1.33 & 1.17 \\
\hline \multicolumn{6}{|l|}{ LC } \\
\hline Sourness & Saltiness ${ }^{\text {ns }}$ & Bitterness & Taste preference & Softness & Texture acceptance \\
\hline 1.44 & 1.47 & 1.5 & 0.83 & 1.06 & 1.08 \\
\hline 1.86 & 1.47 & 2.06 & 0.67 & 2.17 & 2.19 \\
\hline
\end{tabular}

${ }^{\text {ns }}$ Not Significantly different $(\mathrm{P}>0.05)$

\section{AUTHORS' CONTRIBUTIONS}

Murti has presented the idea and wrote the manuscript with support of Puspitasari, Pratiwi, Aranda. While, Pradana has verified the analytical methods. All authors have discussed the final manuscript.

\section{ACKNOWLEDGMENTS}

This study has been financed by the programme RTA 2021 from the ministry of education and culture. For this we appreciate and thanks a lot.

\section{REFERENCES}

[1] Anonymous. 2021. Feta, www. Tasteatlas.com access date 27 August 2021.

[2] Liang, J.B., and P. Paengkoum. 2019. Current status, challenges and the way forward for dairy goat production in Asia - conference summary of dairy goats in Asia. Asian-Australas J Anim Sci Vol. 32, No.8:1233-1243 August 2019 https://doi.org/10.5713/ajas.19.0272 pISSN 1011-2367 eISSN 1976-5517.

[3] Kandarakis, I., G. Moatsou, A.I.K. Georgala, S. Kaminarides, E. Anifantakis. 2001. Effect of draining temperature on the biochemical characteristics of Feta cheese. Food Chemistry 72 (2001) 369 \pm 378 .

[4] Murti, T.W., M. W.E. Perdana, B.P. Alvita and. R. E. Setiawati. 2021. Chemical Characteristic, Microbe and Organoleptic Acceptance oof Probiotic and symbiotic low fat goat cheese. TASJ (accepted for publication).

[5] Murti, T.W., N. Firdaus, E. Robiyati, S. Marta, A.Latif and B.T. Santosa. 2017. Comparison of Ricotta Cheese Containing Single Lactic Acid Bacteria to Those of Mixed Probiotic Bacteria. Short Communication. Proceeding of $7^{\text {th }}$ International seminar on Tropical Animal Production (ISTAP) at UGM Yogyakarta.

[6] Murti, T. W. 2016. Post-Harvest Treatment of Milk. Gadjah Mada University Press. Yogyakarta, Indonesia.

[7] Miller, B. A. and C. D. Lu. 2019. Current status of global dairy goat production: an overview. AsianAustralasia J Anim. Sci Vol. 32, No. 8:1219-1232 August 2019 https://doi.org/10.5713/ajas.19.0253 pISSN 1011-2367 eISSN 1976-5517 
[8] Terpou. A, I. Mantzourani, A. Galanis, M. Kanellaki, E. Bezirtzoglou, A. Bekatorou, A. A. Koutinas and S. Plessas. 2018. Employment of $L$. paracasei K5 as a Novel Potentially Probiotic Freeze-Dried Starter for Feta-Type Cheese Production. Microorganisms 2019, 7, 3; doi:10.3390/microorganisms7010003 